\title{
Rare and frequent postoperative complications after combined pneumonectomy for nonsmall-cell lung cancer
}

\author{
N Lyas ${ }^{1}$, V Khurnin ${ }^{2}$, S Pushkin², A Benyan ${ }^{2 *}$ \\ From 23rd World Congress of the World Society of Cardio-Thoracic Surgeons \\ Split, Croatia. 12-15 September 2013
}

\section{Background}

The rate and structure of postoperative complications after combined pneumonectomy for non small-cell lung cancer depends not only from character of disease, but also because of features of performing operations.

\section{Methods}

The study includes 686 patients who underwent pneumonectomy for primary non-small cell lung cancer (NSCLC) from 2003 through 2012. There were male - 609 (88, 8\%), female -77 (11,2\%). Squamous cell and adenocarcinoma were found in $492(72 \%)$ and $145(21 \%)$ patients, respectively. Right side pneumonectomy was performed at 337 patients, left side - at 349 patients. The combined pneumonectomy was performed at 144 patients $(21 \%)$ : with pericardial resection -75 , wedge carinal resection - 40, circular carinal resection - 12, resection of upper cava vein -13 , of esophagus -7 , of vagus -7 , of costa -5 , of left atrium -3 , of diaphragm -2 , pleurectomy -2 , resection of aortic wall -1 .

\section{Results}

In structure of complications the most frequent was bronchopleural fistula - 29 patients (4,2\%), mortality was $-34,5 \%$. Right side fistula observed in 3 times more often than left sided. After carinal resection frequency of bronchopleural fistula was $9,6 \%$, mortality $-80 \%$. Another complications were: cardiorespiratory insufficiency -9 patients $(1,3 \%)$, intrapleural bleeding -8 $(1,2 \%)$, hemothorax $-3(0,4 \%)$, pulmonary embolism - 6 $(0,9 \%)$, cerebral stroke $-3(0,4 \%)$. Rare complications, those we have also observed, were: cardiac dislocation

\footnotetext{
* Correspondence: armenbenyan@yandex.ru

${ }^{2}$ Samara Regional Clinical Hospital, Samara, Russian Federation

Full list of author information is available at the end of the article
}

occurred after intrapericardial right pneumonectomy with extended pericardioectomy (1 patient), chylothorax (1 patient), mesenteric thrombosis (1 patient), and spontaneous rupture of the esophagus (1 patient). The general rate of complications was $9,5 \%$, mortality $-4,2 \%$.

\section{Conclusions}

So, bronchopleural fistula is the most frequent complication after combined pneumonectomy for nonsmall-cell lung cancer. Variety of other complications depends from severity of disease and volume of primary operation.

\section{Authors' details}

'Samara Regional Oncological Hospital, Samara, Russian Federation. ${ }^{2}$ Samara Regional Clinical Hospital, Samara, Russian Federation.

Published: 11 September 2013

doi:10.1186/1749-8090-8-S1-P134

Cite this article as: Lyas et al:: Rare and frequent postoperative complications after combined pneumonectomy for nonsmall-cell lung cancer. Journal of Cardiothoracic Surgery 2013 8(Suppl 1):P134.

Submit your next manuscript to BioMed Central and take full advantage of:

- Convenient online submission

- Thorough peer review

- No space constraints or color figure charges

- Immediate publication on acceptance

- Inclusion in PubMed, CAS, Scopus and Google Scholar

- Research which is freely available for redistribution

\section{() Biomed Central}

(c) 2013 Lyas et al; licensee BioMed Central Ltd. This is an Open Access article distributed under the terms of the Creative Commons Attribution License (http://creativecommons.org/licenses/by/2.0), which permits unrestricted use, distribution, and reproduction in any medium, provided the original work is properly cited. 